\title{
Perancangan Buku Digital Interaktif Profesi Dunia Aviasi sebagai Media Pengenalan Profesi pada Anak Usia 10-12 Tahun
}

\author{
Cepri Nur Fatullah dan Senja Aprella Agustin \\ Departemen Desain Produk, Fakultas Arsitektur Desain dan Perencanaan, \\ Institut Teknologi Sepuluh Nopember (ITS) \\ e-mail: senja@prodes.its.ac.id
}

\begin{abstract}
Abstrak-Keberadaan profesi penerbangan saat ini menjadi kebutuhan sumber daya manusia dalam industri penerbangan untuk mengimbangi pesatnya pertumbuhan penerbangan, tidak hanya profesi pilot tetapi juga beragam profesi penerbangan lainnya, seperti pemandu lalu lintas udara (ATC), teknisi pesawat dan lain-lain. Akan tetapi pada lingkungan masyarakat, khususnya pada anak-anak, pengenalan profesi penerbangan yang dikenalkan melalui berbagai media masih terbatas pada pilot dan pramugari saja, sehingga refrensi cita-cita anak di dunia penerbangan menjadi tidak luas. Metode penelitian yang digunakan, yaitu pertama penggalian data primer pada stakeholder terkait sebagai identifikasi permasalahan dan penyampaian konten ragam profesi penerbangan. Tahap dua, mengumpulkan data kuesioner pada tiga sekolah dasar di Surabaya yang kemudian diolah sebagai kebutuhan penentuan konten. Tahap ke tiga, melakukan analisa studi eksisting karakter pada buku cerita anak untuk kriteria desain karakter. Selanjutnya, pembuatan prototype yang diujikan pada usia 10-12 tahun sebagai evaluasi hasil akhir. Hasil perancangan ini berupa buku digital interaktif pengenalan profesi penerbangan seri pilot, pemandu lalu lintas udara (ATC), dan teknisi pesawat udara yang dilengkapi dengan narasi cerita, animasi, latar musik sebagai pendukung cerita, dan langkah pencapaian profesi melalui tahap pendidikan.
\end{abstract}

Kata Kunci-buku digital interaktif, profesi penerbangan, citacita, anak usia 10-12 tahun.

\section{PENDAHULUAN}

$\mathrm{P}$ ENERBANGAN sumber merupakan sarana transportasi udara yang selalu memperhatikan sistem keamanan setiap unit profesi penerbangan, seperti awak pesawat, teknisi pesawat loading master, flight operation officer (FOO), pengawas lalu lintas, badan meteorologi dan lain-lain [1]. Pesatnya industri penerbangan di Indonesia merupakan dukungan infrastruktur Kementerian Perhubungan, dimana tahun 2016 dibangun 15 bandara diberbagai daerah, salah satunya bandara Miangas, Sulawesi Utara. Peristiwa tersebut menunjukkan kebutuhan sumber daya manusia pada sektor penerbangan masih banyak dibutuhkan dan bukan hanya pilot tetapi juga jenis profesi penerbangan lainnya, dimana data kementerian perhubungan menyatakan per tahun dibutuhkan 500-100 pilot, 500 tenaga Air traffic Controller (ATC), dan teknisi pesawat udara. Dalam hal tersebut, pemerintah mendirikan sekolah penerbangan, namun keberadaan sekolah penerbangan belum banyak diketahui oleh masyarakat, padahal selain pilot juga di butuhkan oleh industri penerbangan. Kurangnya eksplorasi dan pengetahuan pada jenis profesi penerbangan, menjadikan cita-cita anak hanya mengenal profesi pilot dan pramugari saja. Hal ini dapat diketahui melalui seurvei lapangan oleh penulis kepada 143 responden siswa-siswi kelas 5 SD di Surabaya, menujukkan bahwa total $4 \%$ dari responden yang memiliki cita-cita profesi penerbangan, memilih pilot dan pramugari sebagai cita-cita di dunia penerbangan.

Pengenalan ragam profesi pada anak usia perkembangan sekolah, di harapkan lebih bersifat eksplorasi dan memberikan pengetahuan sederhana tentang pekerjaan profesi karena anak usia 8-12 tahun, mampu menganalisa sifat dan bagian objek serta pengamatan fantasi yang mulai berkurang menjadi pengamatan yang nyata (realitas) [2], dimana seiring dewasa, anak akan menentukan cita-citanya tidak hanya berdasarkan kekagumannya pada tokoh tetapi juga berdasarkan pengalaman yang didapatkannya.

Pengenalan profesi penerbangan juga dikenalkan melalui media board game, buku visual, aplikasi game, dan lain-lain. Akan tetapi konten profesi pada media tersebut masih terbatas pada pilot dan pramugari saja sehingga anak tidak dapat mengeksplor pengetahuannya pada profesi penerbangan. Selain itu pada aplikasi game konten tidak fokus membahas mengenai keprofesian secara langsung serta tidak memberikan informasi lebih lanjut untuk mencapai profesi tersebut.

Seiring perkembangan era digital pada saat ini, pengguna internet di Indonesia mencapai 21\% mulai bulan Maret 2015. Hal ini membuat pengguna smartphone dan media digital berkembang pesat. Salah satunya tren buku digital interaktif yang mulai diminati karena kontennya yang dikemas secara interaktif. Hal ini juga dibuktikan pada data penulis mengenai ketertarikan dari 16 responden anak usia 10-12 tahun pada media buku digital interaktif yang memiliki tingkat ketertarikan sebesar 90\% dan $88 \%$ memilih setuju bahwa cerita yang dikemas dalam buku digital interaktif mudah dipahami oleh anak-anak.

Penggunaan media buku digital interaktif oleh penulis menjadikan peluang untuk mengenalkan macam-macam tokoh profesi penerbangan dalam bentuk aplikasi mobile dengan harapan dapat membantu anak-anak dalam mengeksploras dan memberikan refrensi profesi di bidang penerbangan. 


\section{A. Identifikasi Masalah}

1. Kebutuhan sumber daya manusia di sektor penerbangan belum terpenuhi.

2. Keberadaan sekolah penerbangan tidak banyak diketahui oleh masyarakat dibanding sekolah khusus pilot.

3. Lingkungan sekitar belum banyak memberikan pengetahuan tentang jenis profesi penerbangan pada anak.

4. Terbatasnya konten pada jenis profesi penerbangan dan belum adanya informasi lanjutan tentang pengarahan untuk mencapai profesi tersebut.

5. Kehadiran aplikasi game tentang profesi penerbangan lebih fokus pada hiburan dibandingkan dengan materi pengenalan profesi.

\section{B. Rumusan Masalah}

Bagaimana merancang buku digital interaktif tentang pengenalan macam-macam profesi penerbangan yang mampu mengeksplor pengetahuan cita-cita anak usia 10-12 tahun.

\section{Batasan Masalah}

1. Perancangan buku digital interaktif dibatasi dengan tiga seri cerita penerbangan, yaitu pilot, Air traffic controller (ATC) dan teknisi pesawat.

2. Konten materi profesi yang ditampilkan, yaitu deskripsi dan pengenalan identitas profesi, setting, alat yang digunakan, tugas dan peran, seragam, dan langkah pendidikan untuk mencapai profesi tersebut.

\section{Tujuan}

1. Membantu mengeksplorasi pengetahuan pada anak-anak tentang jenis profesi penerbangan

2. Memberikan referensi atau petunjuk mengenai jenis profesi penerbangan.

3. Memberikan pengalaman dan pemahaman bagi anak melalui tokoh profesi penerbangan.

\section{STUDI PUSTAKA}

\section{A. Landasan Teori}

\section{1) Perkembangan Anak}

Pada dasarnya, anak masa sekolah meletakkan perhatiannya pada dunia luar, aktif, serta kemauan belajar yang kuat [2], karena itu pengenalan profesi merupakan sarana positif bagi anak untuk mengenal ragam profesi penerbangan sesuai minat dan bakatnya.

\section{2) Penerbangan perspektif Profesional}

Berisi keterangan mendasar mengenai profesi penerbangan juga tentang segala sesuatu yang membantu kelancaran penerbangan.

\section{3) Media Pembelajaran}

Dilihat dari sifatnya, media pembelajaran terdiri dari media auditif, visual, audio visual dan multimedia.

\section{4) Buku Digital Interaktif}

Buku digital interaktif merupakan buku berbentuk digital yang mengemas informasi ke dalam bentuk teks, gambar, audio, dan video dengan tidak terikat atau tidak urut dalam pengemasan materinya sehingga pembaca dapat bebas memilih materi. Oleh karena itu terdapat graphical user interface (GUI) untuk dapat dioperasikan [3].

\section{5) User Interface}

Terdapat delapan aturan emas dalam merancang interface, yaitu konsisten, universal, informatif feedback, adanya dialog, intruksi, pencegahan kesalahan aksi, bebas bernavigasi, dan mudah untuk dipelajari [4].

6) Unsur Estetika

Unsur estetika yang diperhatikan dalam merancang buku digital interaktif pengenalan profesi penerbangan ini, yaitu layout, tipografi, gaya gambar, dan warna .

\section{B. Studi Eksisting}

1) Buku Digital Interaktif "The Happy Star"

Buku digital ini memiliki karakteristik sajian narasi dengan animasi, audio, dan alur aplikasi yang mudah dipelajari serta nilai moral sebagai pesan dari cerita.

2) Buku "Ensiklopedia Cilik: Bandara"

Buku cetak ini menceritakan secara detail mengenai narasi maupun penggambaran latar suasana bandara. Setiap tempat yang dijelaskan, juga disisipkan penjelasan tokoh profesi penerbangan secara singkat.

3) Buku Digital Interaktif "All About Airports"

Buku digital ini berisi mengenai pembelajaran animasi dan interaktif yang menjelaskan mengenai isi bandara serta pekerjaan yang dilakukan oleh profesi.

\section{METODOLOGI PENELITIAN}

\section{A. Metode Penggalian Data}

\section{1) Studi literatur}

Studi literatur mengenai perkembangan industri penerbangan, perkembangan anak usia 10-12 tahun, serta jenis media pembelajaran yang digunakan sebagai referensi penyelesaian masalah pada objek yang terkait dalam perancangan ini.

2) Depth-interview

Depth-interview dilakukan kepada tim pengajar Akademi Teknik Keselamatan Penerbangan Surabaya oleh Bapak Rizky dan Bapak Dimas, mengenai pengetahuan pekembangan industri penerbangan di Indonesia dan jenis profesi penerbangan. Selain itu, dilakukan juga pada ahli psikologi, Bapak Rudi Cahyo untuk mengetahui sikap anak terhadap pemilihan profesi serta menentukan target audien perancangan. Kemudian, penulis mengikuti Talk Show Sharing Dongeng oleh Dian Kristiani guna mengetahui unsur penting dalam membuat cerita yang sesuai dengan target anak-anak.

\section{B. Metode Konten Desain}

\section{1) Observasi}

Observasi yang pertama, dilakukan ke tiga sekolah SD di Surabaya, yaitu SDN Rungkut Kidul 1, SDN 1 Gading Kenjeran, SDN Kemayoran 1 Surabaya untuk mengetahui pengetahuan siswa-siswi pada jenis profesi penerbangan. Observasi ke dua dilakukan di Bandara Juanda Surabaya guna studi pengambaran latar suasana bandara. 


\section{2) Kuesioner}

Metode penelitian ini digunakan untuk mendapatkan data kuantitatif dari responden terkait dengan objek perancangan, yaitu:

a. Pengetahuan siswa-siswi pada jenis profesi penerbangan.

b. Mengetahui kebutuhan anak akan apa saja informasi profesi penerbangan yang akan disajikan dalam cerita.

c. Ketertarikan siswa-siswi pada jenis buku bacaan secara visual.

3) Persona

Metode persona digunakan untuk mengetahui karakteristik target audien dalam ketertarikannya menggunakan media digital khususnya smartphone sebagai media hiburan, seperti bermain game, media sosial dan sumber informasi, dengan tujuan agar hasil luaran perancangan ini sesuai dengan kebutuhan atau keinginan audien baik dari segi media atau konten.

\section{ANALISIS HASIL PENELITIAN}

\section{A. Studi literature}

1. Karakteristik kepribadian anak usia 10-12 tahun

2. Perkembangan bahasa pada anak 10-12 tahun

3. Kelebihan multimedia beserta unsurnya

4. Konten cerita

5. Latar suasana

B. Depth-interview

1) Depth-interview ke-1 (Bapak Rizky dan Bapak Dimas)

a. Profesi penerbangan selain pilot dan

b. Pramugari yang terkait dalam menciptakan keamanan penerbangan, juga patut dikenalkan pada masyarakat.

c. Setuju, jika profesi penerbangan disosialisasikan sejak

d. sekolah dasar untuk membangun minat dan dapat menjadi referensi cita-cita di dunia penerbangan.

e. Saran alternatif bagi penulis untuk dapat mendeskripsikan isi dari suatu bandara.

2) Depth-interviewke-2 (Bapak Rudi Cahyo)

a. Konten pengenalan profesi, lebih tepat dikenalkan pada

b. anak usia 10-12 tahun, dimana anak sudah mampu berpikir kritis serta menilai cita-cita sesuai karakternya.

c. Membuat 3-4 kerangka dasar cerita agar menghindari

d. jumlah kata yang banyak.

e. Pengenalan profesi terdiri dari deskripsi profesi serta

f. informasi komponen karir.

3) Talk Show Sharing Dongeng (Kak Dian Kristiani)
a. Menggunakan kata hiperbola.
b. Buat tulisan yang melibatkan anak.
c. Jelas dan akurat.
d. 4 unsur cerita, yaitu beginning, middle, falling action,
e. dan ending.

\section{Observasi}

1. Total 143 siswa-siswi dari ke tiga SD di Surabaya hanya

2. mengetahui pilot dan pramugari saja karena berdasarkan

3. nilai popular dan lebih berwibawa.

4. Observasi di bandara Juanda Surabaya guna mendapatkan
5. referensi latar suasana.

\section{Kuesioner}

1. Pengetahuan terendah oleh responden pada profesi

2. penerbagan, yaitu pada profesi teknisi sebesar $3 \%$ dan pemandu lalu lintas udara 5\%. Hal tersebut menjadi dasar pemilihan profesi yang akan disajikan dalam cerita.

3. Profesi pilot dipilih kembali karena $74 \%$ anak tertarik

4. pada profesi yang terlibat dalam proses penerbangan, yaitu pilot.

5. Hampir semua aspek informasi profesi dianggap

6. penting untuk disajikan, terutama aspek langkah pendidikan profesi yang dipilih sebesar $29 \%$ dan keahlian profesi $26 \%$

7. $70 \%$ anak-anak tertarik pada buku yang memiliki banyak

8. Ilustrasinya.

\section{E. Persona}

Karakteristik target audien dari perancangan ini, yaitu anak laki-laki dan perempuan usia 10-12 tahun yang menggunakan smartphone untuk bermain game dan bermedia sosial, seperti instagram, facebook, dan whatsapp. Selain itu, dari hasil penelitian survei lapangan oleh penulis yang dilakukan pada 16 responden, bahwa 90\% anak tertarik pada media buku digital interaktif dan $88 \%$ setuju pada kemudahan kontennya.

\section{KONSEP DAN APLIKASI DESAIN}

\section{A. Poitioning produk}

Dari hasil riset, dihasilkan konsep media berupa buku digital interaktif dalam bentuk aplikasi mobile melalui system operasi Android dengan pendekatan komunikasi interaktif, yaitu dalam bentuk animasi, narasi, ilustrasi dan musik latar. Materi dalam buku digital ini lebih memfokuskan mengenai informasi keprofesian yang ada pada profesi agar mampu membangun imajinasi anak tentang pengetahuan profesi penerbangan.

\section{B. Target Audien}

Target audien dari perancangan buku digital interaktif pengenalan profesi penerbangan ini, antara lain memiliki karakteristik sebagai berikut:

1. laki-laki dan perempuan (10-12 tahun)

2. aktif dan menyukai jenis hobi berolahraga

3. menggunakan smartphone untuk bermain game dan bermedia sosial

4. menggunakan smartphone dengan waktu rata-rata sejam sehari.

\section{Konsep Desain}

Big idea atau konsep desain dari perancangan ini, yaitu "Kini lebih dekat menuju impian profesi penerbangan", dimana buku digital ini menjelaskan jenis profesi penerbangan pada anak dengan menggunakan pendekatan komunikasi yang interaktif sehingga memudahkan anak memahami cerita dan lebih dekat atau akrab dengan pengetahuan jenis profesi penerbangan. 


\section{Hierarki Konten}

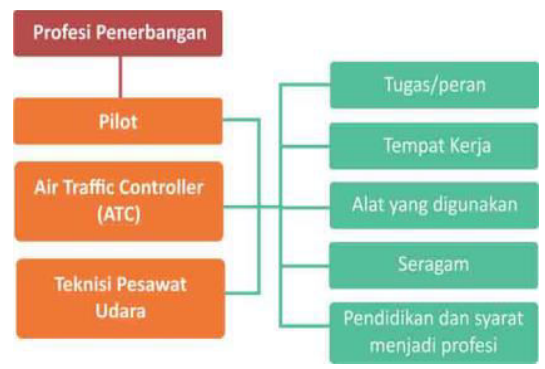

Gambar 1. Bagan Hierarki Konten.

Bagan di atas merupakan urutan konten setiap materi cerita profesi penerbangan yang meliputi tugas, tempat kerja, alat yang digunakan, seragam serta langkah pendidikan profesi.

\section{E. Warna}

Warna yang digunakan dalam buku digital interaktif ini menggunakan warna colorful yang terdiri dari tiga warna dalam proses cetak, yaitu cyan, magenta, dan kuning. Warna tersebut memiliki makna ceria, semangat dan menarik yang terkait erat dengan anak.

Gambar 2. Warna colorful.

\section{F. Karakter}

Penggambaran karakter dilakukan dengan meninjau ulang karakter yang ada pada eksisting buku cerita anak dengan hasil pemilihan karakter yang memiliki ciri visual penyederhanaan bentuk anggota tubuh, kepala yang besar, dan digambarkan seperti fisik tubuh anak-anak.

1) Karakter utama

Berikut merupakan karakter utama, yaitu Alan dan Stella yang akan mengenalkan pembaca pada jenis profesi penerbangan.

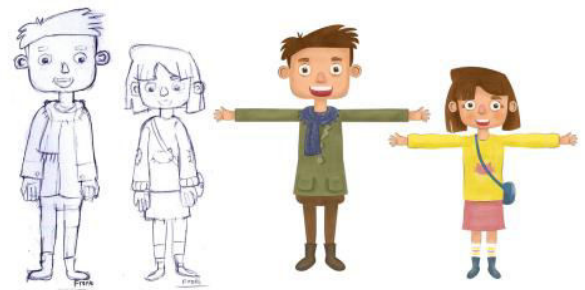

Gambar 3. Karakter utama.

Sumber: Fatullah, 2016

2) Karakter profesi penerbangan

Di bawah ini merupakan masing-masing karakter profesi penerbangan, antara lain pilot, pemandu lalu lintas udara (ATC) dan teknisi pesawat udara.
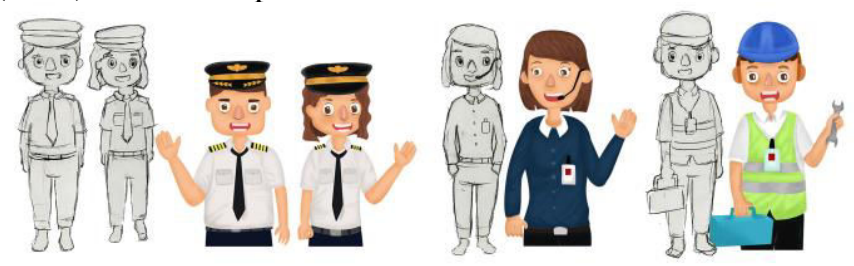

Gambar 4. Karakter penerbangan.

\section{G. Latar Suasana}

Latar suasana yang digunakan yaitu, suasana tempat kerja dari profesi pilot, pemandu lalu lintas udara, dan teknisi pesawat yang meliputi: kokpit pesawat, menara bandara, lapangan udara, dan hanggar pesawat.
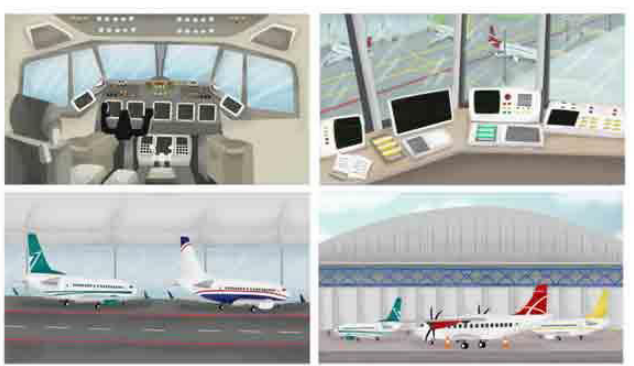

Gambar 5. Latar suasana cerita.

\section{H. Desain Interface}

\section{1) Struktur Navigasi}

Dibawah ini merupakan struktur alur navigasi pada buku digital yang terdiri dari homescreen, halaman menu, halaman narasi, dan halaman penutup. Pembaca dapat melanjutkan seri berikutnya apabila pembaca telah menyelesaikan cerita seri profesi sebelumnya.

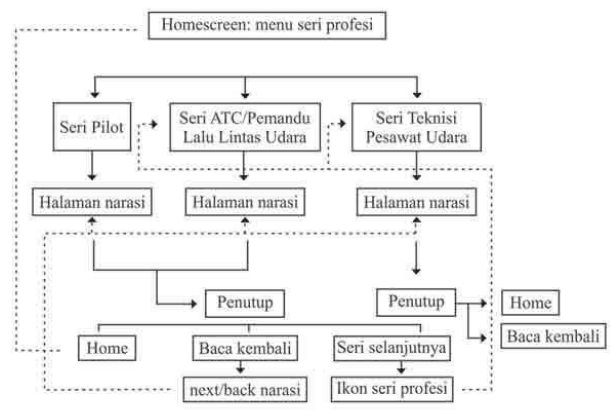

Gambar 6. Struktur navigasi buku interaktif digital.

2) Elemen Interface

Elemen interface yang terdapat pada buku digital interaktif ini, terdiri dari logo aplikasi, tombol ikon dan teks, kotak narasi, ikon profesi dan kotak dialog sebagai notifikasi aksi.

a. Logo Aplikasi

Logo yang digunakan terdiri dari gabungan logotype dan logogram yang menampilkan karakter utama Alan dan Stella serta judul aplikasi "adventure in the Airport".

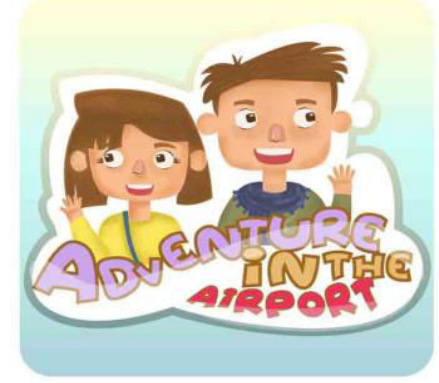

Gambar 7. Logo aplikasi. 
b. Tombol Navigasi dan ikon profesi

Tombol navigasi pada buku digital ini berbentuk ikon dan teks yang berguna bagi pembaca untuk mengoperasikan aplikasi buku digital ini. Selain itu, terdapat ikon profesi sebagai menu cerita.
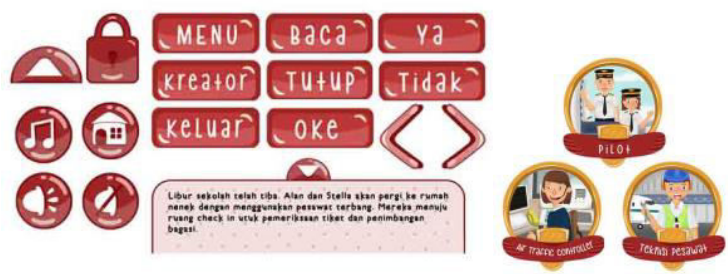

Gambar 8. Tombol navigasi dan ikon profesi.

\section{Konsep Bisnis dan Pengembangan}

\section{1) Promosi}

Promosi yang dilakukan, yaitu menggunakan iklan video di instagram. Penayangan iklan melalui instagram disesuaikan dengan kebiasaan target audien yang rata-rata menggunakan smartphone untuk bermain media sosial, salah satunya instagram. Selain itu, penambahan caption untuk menarik pengguna agar mengunduh aplikasi buku digital ini.
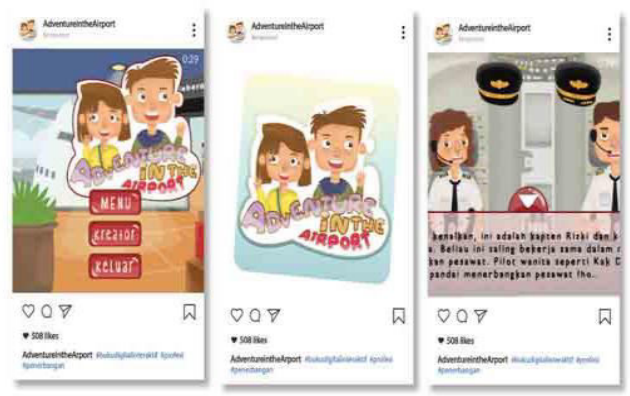

Gambar 9. Iklan video promosi Instagram.

2) Distribusi

Buku digital interaktif ini di distribusikan melalui Google Play secara gratis dengan tiga seri cerita penerbangan, antara lain, pilot, pemandu lalu lintas udara (ATC) dan teknisi pesawat udara.

\section{J. Implementasi Desain}

Ilustrasi, narasi dan unsur interface yang telah di desain, kemudian di terapkan dalam aplikasi buku digital interaktif. Berikut merupakan penerapan desain berdasarkan urutan tampilan dalam alur navigasi.

\section{1) Halaman Utama dan Menu}

Pada halaman utama atau homescreen berisi menu dan tombol navigasi yang dapat membantu pengguna untuk mengoperasikan aplikasi buku digital ini, sedangkan halaman menu merupakan informasi daftar jenis profesi penerbangan yang disajikan dalam buku digital.

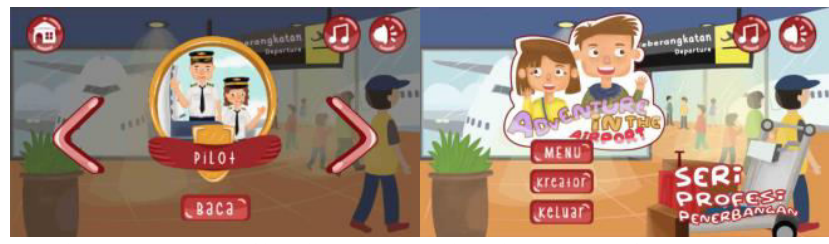

Gambar 10. (a) Tampilan homescreen dan (b) menu cerita.

\section{2) Halaman Cerita}

a. Tugas atau Peran

Contoh halaman cerita ini, menjelaskan tugas dan peran dari ke tiga jenis profesi melalui kotak narasi yang dapat dimunculkan dan disembunyikan oleh pengguna.

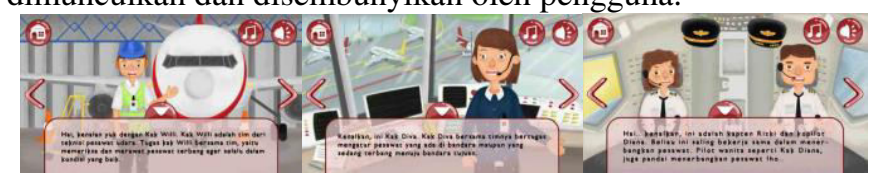

Gambar 11. Halaman cerita: tugas atau peran profesi.

\section{b. Tempat Kerja}

Pada halaman cerita berikutnya, menggambarkan dan menjelaskan tempat kerja dari masing-masing profesi.

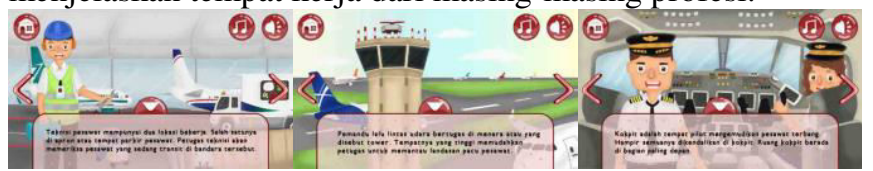

Gambar 12. Halaman cerita: tempat kerja profesi.

\section{c. Alat yang digunakan Profesi}

Halaman selanjutnya merupakan informasi mengenai alat yang digunakan oleh ke tiga jenis profesi dalam membantu tugasnya.

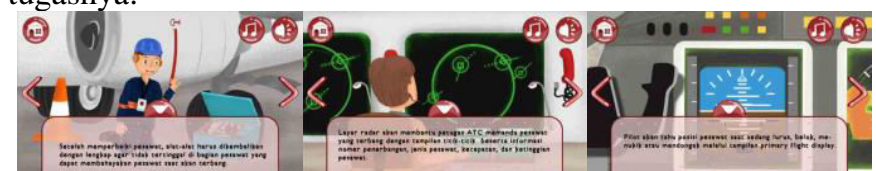

Gambar 13. Halaman cerita: alat yang digunakan profesi.

d. Seragam Profesi

Di bawah ini merupakan halaman cerita yang menjelaskan seragam yang dipakai oleh profesi penerbangan saat bertugas.

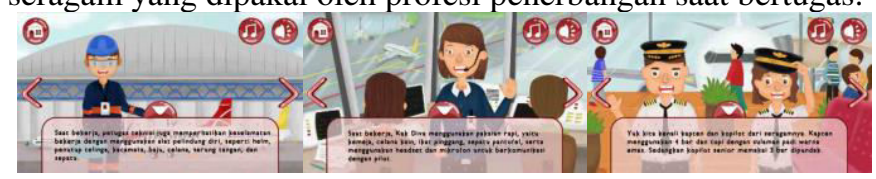

Gambar 14. Halaman cerita: seragam profesi.

e. Pendidikan dan Syarat Profesi

Halaman akhir cerita, yaitu berisi mengenai informasi langkah pendidikan dan syarat untuk dapat mencapai profesi penerbangan.

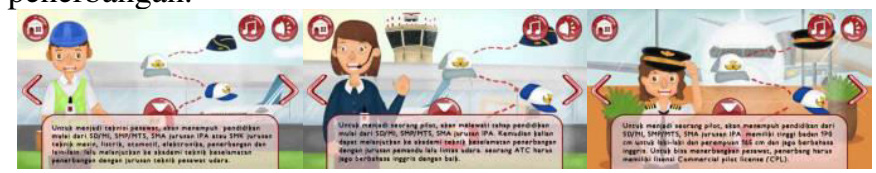

Gambar 15. Halaman cerita: pendidikan dan syarat profesi.

\section{3) Halaman Penutup}

Pada halaman penutup merupakan tampilan akhir dari alur aplikasi yang menandakan pengguna telah berhasil menyelesaikan bacaan seri profesi penerbangan pada buku digital ini.

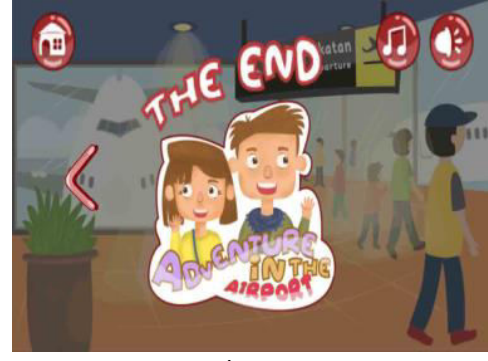

Gambar 16. Halaman cerpenutup cerita. 


\section{4) Tampilan Pop-up Kotak Dialog dan Intruksi}

Berikut merupakan implementasi desain kotak dialog dan intruksi guna membantu pengguna dalam mengoperasikan aplikasi.

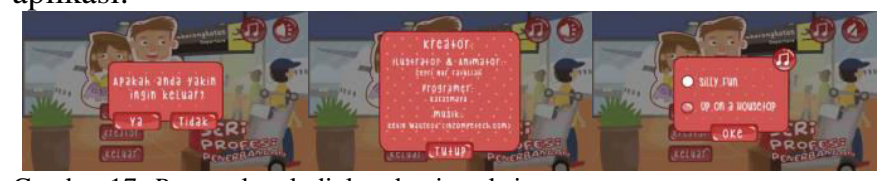

Gambar 17. Pop-up kotak dialog dan intruksi.

\section{KESIMPULAN}

Dari hasil penelitian dan konsep perancangan buku digital interaktif profesi penerbangan ini, dapat menjadi alternatif media dalam mengenalkan jenis profesi penerbangan yang disusun sesuai dengan keinginan dan kebutuhan target audien anak usia 10-12 thaun, sehingga dapat mengeksplor pengetahuan dan memberikan referensi cita-cita anak di bidang penerbangan. Hasil dari uji coba buku digital ini menunjukkan respon positif dari audien dengan tingkat kepuasan sebesar $92.67 \%$, dimana audien sangat mudah dalam menggunakan aplikasi, memahami isi materi serta menyukai tampilan dari aplikasi. Demikian kesimpulan dari perancangan ini, semoga dapat menjadi referensi bagi pembaca yang ingin mengembangkan penelitian ini dari segi konten jenis profesi maupun materi profesi penerbangan selain yang telah disampaikan pada perancangan ini.

\section{DAFTAR PUSTAKA}

[1] D. Hutagaol, Pengantar Penerbangan Perspektif Profesional. Jakarta: Erlangga, 2012.

[2] Z. L., Psikologi Perkembangan. Bandung: PT Remaja Rosdakarya, 1986.

[3] W. Sanjaya, Media Komunikasi Pembelajaran. Jakarta: Kencana Prenada Media Group, 2012.

[4] S. Shneiderman and P. Plaisant, "Delapan aturan emas dalam merancang Interface,” Bina Nusantara, 2013. 